\title{
Resource Conservation Technology in Pigeonpea (Cajanus cajan (L.) Mill sp.) through Tillage and Mulching
}

\author{
Karri Pramodha Eswari Mounika*, Jamkhogin Lhungdim, \\ Herojit Singh Athokpam and N. Okendro Singh
}

College of Agriculture, Central Agricultural University, Imphal-795004, India

*Corresponding author

\begin{abstract}
A B S T R A C T
\section{Keywords}

Conventional tillage, Zero tillage, Weed biomass mulch, Natural resource conservation

\section{Article Info}

Accepted: 24 August 2020 Available Online: 10 September 2020

Field experimentation was conducted during kharif season of 2019 at Research Farm, College of Agriculture, Central Agricultural University, Imphal, India to evaluate the "Resource conservation technology in pigeonpea (Cajanus cajan (L.) Millsp.) through tillage and mulching". Among the various treatments, the treatment (L1M3) conventional tillage with weed biomass mulch recorded significantly highest number of branches, highest number of pods per plant and highest yield. Likewise, gross return (Rs.153416/ha) and net return (Rs.110621/ha) was found best in (L1M3) conventional tillage with weed biomass mulch and benefit cost ratio (2.8) were recorded significantly higher in (L3M3) zero tillage along with weed biomass mulch whereas the lowest gross return (Rs. $74421 / \mathrm{ha}$ ) recorded in (L3M4) receiving zero tillage with zero mulch, lowest net return (Rs. 42601/ha) and benefit cost ratio (1.2) were obtained from the treatment (L3M2) receiving zero tillage with rice straw mulch. Hence best natural resource conservation was observed in L3M3 treatment.
\end{abstract}

\section{Introduction}

Pigeonpea (Cajanus cajan L.) belongs to Leguminosae family, originated in India and is second most important crop in India. It is also known as Arhar/Red gram. It is consumed exclusively as dal, rich in protein (21\%), iron and iodine. It is also rich in amino acids like lysine, tyrosine, cysteine and arginine. In some parts of India, green pods are used as vegetable. The pod husk and seed husk are used as feed for cattle. The dry sticks are used for thatching and fuel purposes. The deep root system improves physical properties of the soil. Pigeonpea being a legume possess valuable property such as enriching nitrogen in soil. The plants shed large amounts of leaves, which add organic matter to soil. Pigeonpea or red gram having a long duration with very slow vegetative growth habit up to 50 to 65 DAS, facilitates the weeds to grow luxuriantly leading to even more than $75 \%$ yield loss and also complete crop failure under uncontrolled condition (Channappagoudar and Biradar, 2010).

Tillage based conventional agriculture is assumed to have led to soil organic matter 
decline, water runoff and soil erosion and other manifestation of physical, chemical and biological soil degradation (Benites, 2008).

Conservation tillage practices have received considerable attention over the past few decades due to increasing concern of sustainability of agri-production system vis-àvis food security in near future. No tillage is usually reported to increase the soil bulk density in initial years and therefore, makes the soil more compact at surface but lesser in sub-surface (López-Fando et al., 2007). Tillage requirements of pigeonpea are one of the important aspects in successful raising of the crop. Tillage operations help in controlling pest, diseases and weeds also in conserving soil moisture. This also helps in increasing soil aeration which helps in root penetration and proliferation enabling the crop to draw water and nutrients from deeper layers of soil, thus helping in crop productivity.

Mulch is a layer of dissimilar material separating the soil surface from the atmosphere and mulching is the artificial application of mulch, practiced to obtain beneficial changes in the soil environment. Mulch may be organic (crop residues, stubble mulch etc.) or inorganic (plastic sheet, gravels etc.) in nature. Mulching improves the physical conditions, chemical environment and biological activities of soil.

Favourable modification of the soil hydrothermal regime, improvement of soil aggregation and retardation of erosion and soil loss enhance the physical condition of soil under mulch. Low cost biodegradable mulches are alternatives to black polyethylene (PE) mulch. Rice straw, barley straw, maize harvest residue, absinth wormwood plants, black biodegradable plastic, brown craft paper, etc. can be used as mulching materials.

\section{Materials and Methods}

A Field experiment was conducted during kharif season of 2019 at Research Farm, College of Agriculture, Central Agricultural University, Imphal to study Resource conservation technology in pigeonpea (Cajanus cajan (L.) Millsp.) through tillage and mulching. The soil of the experimental site was acidic with $\mathrm{pH} 5.45$, available nitrogen $292 \mathrm{~kg}$ ha-1, available phosphorous $20.7 \mathrm{~kg}$ ha-1, available potash $213.3 \mathrm{~kg}$ ha-1 and organic carbon $1.2 \%$. The experiment was laid out in Factorial Randomized Block Design (FRBD) with three replications consisting of three tillage treatments viz. conventional tillage (L1), minimum tillage (L2) and zero tillage (L3) and four mulching treatments viz. cement bag mulch (M1), rice straw mulch (M2), weed biomass mulch (M3) and no mulch (M4). The total rainfall received during the crop season was 717.7 $\mathrm{mm}$. The variety was BRG-4. The experimental field was ploughed by tractor two times followed by one harrowing (deeply tilled $25-30 \mathrm{~cm}$ ) in conventional tillage plots, one time ploughing $(15 \mathrm{~cm} \mathrm{dept)} \mathrm{followed} \mathrm{by}$ one harrowing in minimum tillage plots and there was no tillage practices done in zero tillage plots. Mulching was done as per the treatments on the date of sowing. The crop was line sown with seed rate of $10 \mathrm{~kg} / \mathrm{ha}$ on 6th June, 2019. A common fertilizer dose of 25,40 and $30 \mathrm{~kg}$ of $\mathrm{N}, \mathrm{P}$ and $\mathrm{K}$ per ha, respectively was applied. Full dose of $\mathrm{P}_{2} \mathrm{O}_{5}$, $\mathrm{K}_{2} \mathrm{O}$ and $\mathrm{N}$ were applied one day prior to sowing. Plant protection measures were provided as and when required. The crop was harvested on 11th February, 2020. All the data obtained were statistically analysed by the method of analysis of variance to test the significance of the treatment effects as well as result interpretation as given by Gomez and Gomez (1984). F-test at 5\% level of probability was used to test the significance of treatment effect and wherever the " $F$ " test was 
significant critical difference (CD) values were given at $5 \%$ level of significance.

\section{Results and Discussion}

\section{Effect of tillage on growth and yield}

The results of pigeonpea plant height and number of branches as influenced by tillage treatments were mentioned in Table 1 . The mean plant height significantly influences tillage practices at all the four stages of recording. Significantly highest plant height records in Conventional tillage (L1) practice $(299.20 \mathrm{~cm})$, irrespective of the stages and this is significantly higher compared to Minimum tillage (L2) and Zero Tillage (L3) plants. This follows by the Minimum tillage (L2) readings and the least plant height observes in Zero tillage (L3) plants in all the growth stages. The mean number of branches per plant also significantly influences tillage practices. Significantly maximum number of branches records in Conventional tillage (L1) practice (23.03) irrespective of the stages and this is significantly higher compared to Minimum tillage (L2) and Zero Tillage (L3) plant branches. This follows by the $\mathrm{L} 2$ readings and the least number of branches observes in L3 plants in all the growth stages. It might be due to the reason that plants sown under conventional tillage, that loosens the compact soil layer which helps in improving the physical condition of the soil with respect to better tilth, enhanced infiltration rate, water movement, crop root growth, increased crop nutrition uptake, less crop weed competition thus enhancing subsequent plant growth leading to higher plant height and number of branches. This observation was supported by the recordings of Gajri et al., (1991), Arora et al., (1993) Rathore et al., (1998), Elnazif et al., (1999) and Ved Singh (2000).

The effect of tillage on pigeonpea in terms of yield attributes and yield are presented in
Table 1. The recordings shows that tillage practices have significant effect on yield attributes and yield.

The maximum mean number of pods per plant observes in Conventional tillage (L1) with (126.90) pods per plant also the maximum grains per pod (4.88) and the test weight $(121.54 \mathrm{~g})$ also records highest in Conventional tillage (L1). This follows by the Minimum tillage (L2) and the least obtains in Zero tillage (L3) plots. The maximum yield per plot is also observed in Conventional tillage (L1) with $(1930.93 \mathrm{~kg} / \mathrm{ha})$. This follows by the Minimum tillage (L2) with $(1467.30 \mathrm{~kg} / \mathrm{ha})$. The minimum grain yield records in Zero tillage (L3) plots with $(1293.79 \mathrm{~kg} / \mathrm{ha})$. It might be due to good soil tilth, better aeration, less crop-weed competition providing better nourishment to the crop, enabling uniform distribution of sunlight throughout the reproductive growth enabling the crops to partition dry matter towards grains, higher root growth and increased nutrient uptake might be the reason for greater biomass production of the crop thus enhancing subsequent plant growth leading to higher number of branches, higher number of pods per plant, higher number of grains per pod and test weight resulting in higher grain yield. The similar results was also observed in Sutarto et al., (1992), Trivedi et al., (1994) and Ved Singh (2000), Dogra et al., (2002), Bhatt et al., (2004), Gursoy et al., (2010) and Samanth and Patra (2016).

\section{Effect of mulching on growth and yield}

The mean plant height significantly influences different mulching practices at all observation intervals. The maximum plant height (299.97) records in Rice straw mulch (M2) and it is significantly higher over the rest of the treatments. This follows by the Cement bag mulch (M1) and this remains at par with Weed biomass mulch (M3). The least plant 
height records in No mulch treatment. Significantly maximum number of branches also records in Weed biomass mulch (M3) with (22.28) mean number of branches per plant, follows by Cement bag mulch (M1) and this remains at par with Rice straw mulch (M2). The No mulch (M4) treatment records with minimum number of branches per plant.

Table.1 Effect of tillage and mulching on growth and yield attributes of pigeonpea

\begin{tabular}{|c|c|c|c|c|c|c|}
\hline Treatment & $\begin{array}{l}\text { Plant } \\
\text { height }\end{array}$ & $\begin{array}{c}\text { Number of } \\
\text { branches }\end{array}$ & $\begin{array}{l}\text { Number of } \\
\text { pods per } \\
\text { plant }\end{array}$ & $\begin{array}{l}\text { Grains per } \\
\text { pod }\end{array}$ & $\begin{array}{l}\text { Test weight } \\
\text { (g) }\end{array}$ & $\begin{array}{c}\text { Grain yield } \\
\text { (kg/ha) }\end{array}$ \\
\hline \multicolumn{7}{|l|}{ Tillage } \\
\hline Conventional tillage (L1) & 299.20 & 23.03 & 126.90 & 4.88 & 121.54 & 1930.92 \\
\hline Minimum tillage (L2) & 285.62 & 19.89 & 97.51 & 4.53 & 117.83 & 1467.38 \\
\hline Zero tillage (L3) & 267.04 & 18.17 & 69.29 & 4.43 & 108.54 & 1293.79 \\
\hline $\operatorname{S.E}(d)( \pm)$ & 6.40 & 0.42 & 2.00 & 0.14 & 3.41 & 32.11 \\
\hline C.D $(P=0.05)$ & 13.27 & 0.86 & 4.15 & 0.29 & 7.07 & 66.59 \\
\hline \multicolumn{7}{|l|}{ Mulching } \\
\hline Cement bag mulch (M1) & 289.18 & 21.10 & 101.61 & 4.80 & 124.10 & 1654.67 \\
\hline Rice straw mulch (M2) & 299.97 & 19.88 & 93.86 & 4.64 & 114.32 & 1479.78 \\
\hline Weed biomass mulch (M3) & 279.90 & 22.28 & 124.39 & 4.62 & 116.60 & 1835.28 \\
\hline No mulch (M4) & 266.77 & 18.19 & 71.73 & 4.40 & 108.87 & 1286.39 \\
\hline $\operatorname{S.E}(d)( \pm)$ & 7.39 & 0.48 & 2.31 & 0.16 & 3.94 & 37.08 \\
\hline C. $\mathrm{D}(\mathrm{P}=0.05)$ & 15.32 & 0.99 & 4.79 & 0.34 & 8.16 & 76.90 \\
\hline
\end{tabular}

Interaction

\begin{tabular}{|l|l|l|l|l|l|l|}
\hline L1M1 & 308.13 & 24.67 & 131.98 & 4.87 & 125.60 & 2046.67 \\
\hline L1M2 & 307.03 & 21.33 & 118.46 & 5.07 & 119.97 & 1842.00 \\
\hline L1M3 & 302.63 & 25.60 & 152.33 & 4.93 & 124.40 & 2191.67 \\
\hline L1M4 & 279.00 & 20.50 & 104.83 & 4.67 & 116.20 & 1643.33 \\
\hline L2M1 & 285.30 & 19.63 & 102.57 & 4.80 & 128.53 & 1527.00 \\
\hline L2M2 & 286.37 & 20.17 & 101.63 & 4.33 & 113.87 & 1492.67 \\
\hline L2M3 & 290.81 & 21.13 & 116.03 & 4.67 & 118.00 & 1697.17 \\
\hline L2M4 & 280.00 & 18.63 & 69.80 & 4.33 & 110.93 & 1152.67 \\
\hline L3M1 & 274.10 & 19.00 & 70.28 & 4.73 & 118.17 & 1390.33 \\
\hline L3M2 & 306.50 & 18.13 & 61.50 & 4.53 & 109.13 & 1104.67 \\
\hline L3M3 & 246.27 & 20.10 & 104.80 & 4.27 & 107.40 & 1617.00 \\
\hline L3M4 & 241.30 & 15.43 & 40.57 & 4.20 & 99.47 & 1063.17 \\
\hline S.E(d)( \pm ) & 12.80 & 0.83 & 4.00 & 0.28 & 6.82 & 64.22 \\
\hline C.D (P=0.05) & 26.49 & 1.71 & 8.30 & NS & NS & 132.93 \\
\hline
\end{tabular}


Table.2 Effect of tillage and mulching on economics of pigeonpea

\begin{tabular}{|c|c|c|c|}
\hline Treatments & Gross income (Rs./ha) & Net income (Rs./ha) & B:C ratio \\
\hline L1M1 & 143266.67 & 91471.67 & 1.76 \\
\hline L1M2 & 128940.00 & 81145.00 & 1.7 \\
\hline L1M3 & 153416.67 & 110621.67 & 2.58 \\
\hline L1M4 & 115033.33 & 76888.33 & 2.0 \\
\hline L2M1 & 106890.00 & 60455.00 & 1.3 \\
\hline L2M2 & 104486.67 & 62051.67 & 1.46 \\
\hline L2M3 & 118801.67 & 81366.67 & 2.2 \\
\hline L2M4 & 80686.67 & 47901.67 & 1.46 \\
\hline L3M1 & 97323.33 & 58598.33 & 1.5 \\
\hline L3M2 & 77326.67 & 42601.67 & 1.22 \\
\hline L3M3 & 113190.00 & 83465.00 & 2.8 \\
\hline L3M4 & 74421.67 & 49346.67 & 1.96 \\
\hline
\end{tabular}

This result might be possible due to the addition of organic matter to the soil by gradual decomposition of organic mulches and supply nutrients to the plant which helps for its growth and development. Similar results was also recorded in findings of Osuji (1990), Subrahmaniyan et al., (2002), Ahmed et al., (2007) and Chinnathurai et al., (2012). There is a significant effect of mulching on yirld and yield attributes in pigeonpea. The maximum number of pods per plant (124.39) and yield per plot $(1835.28 \mathrm{~kg} / \mathrm{ha})$ is observed in Weed biomass mulch (M3) plots. This is followed by Cement bag mulched (M1) plots which is almost at par with Rice straw mulch (M2) plots. The least number of pods and yield per plot records in No mulch (M4) plots.

The maximum number of grains per pod (4.80) and test weight $(124.10 \mathrm{~g})$ is observed in Cement bag mulch (M1) plots. This is followed by Weed biomass mulched (M3) plots which is almost at par with Rice straw mulch (M2) plots and least is recorded in no mulch treated plots.

These results are due to the less weed crop competition and addition of organic matter gradually into the soil which supplies nutrients to plant that helps in growth and development especially during its reproductive stage. These findings were almost similar with Gajera and Ahlawat (2002), Bhatt et al., (2004), Subrahmaniyan et al., (2002), Ramesh and Devasenapathy (2007) and Chinnathurai et al., (2012).

\section{Interaction effect of tillage and mulching on growth and yield}

Interaction between tillage and mulching on plant height also found significant with treatment combination, Conventional tillage with Cement bag mulch (L1M1) with maximum interaction mean plant height $(308.13 \mathrm{~cm})$ and minimum plant height records in treatment combination Zero tillage with No mulch (L3M4). Highest number of branches per plant (25.60), number of pods per plant (152.33) and yield (2191.67 kg/ha) is observed in treatment combination Conventional tillage with Weed biomass mulch (L1M3) and minimum is recorded in Zero tillage with No mulch (L3M4) treatment. Similar findings were recorded by Gajera $e t$ al., (1998), Mupangwa et al., (2007) and Mondal et al., (2013).

\section{Economics}

The effect of tillage and mulching in pigeonpea was estimated in terms of 
economics is presented in Table 2. Among the various treatments the highest gross return (Rs.153416/ha) and net return (Rs.110621/ha) was found best in (L1M3) conventional tillage with weed biomass mulch and benefit cost ratio (2.8) were recorded significantly higher in (L3M3) zero tillage along with weed biomass mulch whereas the lowest gross return (Rs. 74421/ha) recorded in (L3M4) receiving zero tillage with zero mulch, lowest net return (Rs. 42601/ha) and benefit cost ratio (1.2) were obtained from the treatment (L3M2) receiving zero tillage with rice straw mulch. Similar findings were also reported by Lal (2007), Ramesh and Devasenapathy (2007), Kumar et al., (2015) and Samanth and Patra (2016). On the basis of result obtained from the present investigation, it can be concluded that the Pigeonpea responded well to treatment combination Conventional tillage + Weed biomass mulch with highest monetary benefits in terms of net return and maximum benefit cost ratio was associated with the treatment combination Zero tillage + Weed biomass mulch. Hence this treatment combination can be adopted effectively and economically without notable reduction in yield from the rest of the treatments.

\section{References}

Ahmed, Z.I., Ansar, M., Iqbal, M. and Minhas, N.M. (2007). Effect of planting geometry and mulching on moisture conservation, weed control and wheat growth under rainfed conditions.
Pakistan Journal of Botany, 39(4): 1189. Arora, V.K., Gajri, P.R. and Chaudhary, M.R. (1993). Effect of conventional and deep tillage on mustard for efficient water and nitrogen use in coarse tectured soils. Soil and tillage Research, 26(4): 327-340.

Benites, J.R. (2008). Effect of no-till on conservation of the soil and soil fertility. No-Till Farming Systems, 3(1): 59-72.

Bhatt, R., Khera, K.L. and Arora, S. (2004). Effect of tillage and mulching on yield of corn in the submontaneous rainfed region of Punjab, India. International Journal of Agriculture and Biology, 6(1): 126-128.

Channappagoudar, B.B. and Biradar, N.R. (2010). Physiological approaches for weed management in soybean and redgram (4:2 rp) intercropping system. Karnataka Journal of Agricultural Sciences, 20(2): 151-154.

Chinnathurai, S.J., Veeramani, A. and Prema, P. (2012). Weed dynamics, yield and economics of pigeonpea influenced by growth promoters and mulching. Indian Journal of Weed Science, 44(3): 186-190.

Dogra, P., Joshi, B.P. and Sharma, N.K. (2002). Economic analysis of tillage practices for maize cultivation in the Himalayan humid subtropics. Indian Journal Soil Conservation, 30(2): 172178.

Elnazif, S.A., Luo, X. and Luo, X.W. (1999). The effect of different tillage management and working depth on maize production. Journal South China Agricultural University, 20(2): 85-90.

\section{How to cite this article:}

Karri Pramodha Eswari Mounika, Jamkhogin Lhungdim, Herojit Singh Athokpam and Okendro Singh, N. 2020. Resource Conservation Technology in Pigeonpea (Cajanus cajan (L.) Millsp.) through Tillage and Mulching. Int.J.Curr.Microbiol.App.Sci. 9(09): 3246-3251. doi: https://doi.org/10.20546/ijcmas.2020.909.402 